\title{
Hubungan Status Gizi dengan Kejadian Sindrom Pre Menstruasi Pada Siswi SMA Wirausaha Bandungan Tahun 2016
}

\author{
Bulan Purnama Sari1, Priyanto2 \\ 1,2 Fakultas Ilmu Keperawatan, Universitas Ngudi Waluyo
}

\section{Article Info}

Article History:
Accepted November 26rd
2018

Key words:

Status Gizi

Kejadian Sindrom Pre

Menstruasi

\section{PENDAHULUAN}

Masa remaja atau masa puber merupakan masa penghubung antara masa anak-anak dengan dewasa. Memasuki usia remaja, beberapa jenis hormone, terutama hormone esterogen dan progesterone, mulai berperan aktif sehingga pada diri anak perempuan mulai tumbuh payudara,

\begin{abstract}
Angka kejadian PMS di Indonesia dialami 70\%-90\% oleh wanita usia reproduktif dan 2\%-10\% mengalami gejala Premenstrual Syndrome berat. Bagi beberapa wanita gejala PMS dapat terjadi cukup parah, sehingga dapat menimbulkan dampak yang merugikan. Salah satu faktor risiko sindrom premenstruasi adalah indeks massa tubuh (IMT). Status gizi ini memiliki peranan yang cukup penting pada tingkat keparahan kejadian PMS. Hal ini dikarenakan seseorang yang mengalami kegemukan atau obesitas dapat meningkatkan risiko terjadinya peradangan (inflamasi) yang berujung pada meningkatnya risiko mengalami gejala PMS. Penelitian ini bertujuan untuk mengetahui Hubungan Status Gizi dengan Kejadian Sindrom Pre Menstruasi pada siswi SMA Wirausaha Bandungan. Jenis penelitian yang digunakan adalah analitik kolerasi dengan menggunakan pendekatan cross sectional. Responden adalah semua Siswi SMA Wirausaha Bandungan yang berjumlah 79 orang. Teknik pengambilan sampel dengan purposive sampling. Analisis statis menggunakan uji chi square dengan taraf signifikan 0,05. Hasil penelitian didapatkan sebagian besar responden mengalami status gizi dalam kategori gemuk sebanyak 33 orang $(41,8 \%)$, sebagian besar responden mengalami sindrom pre menstruasi sebanyak 41 orang $(51,9 \%)$ dan didapatkan p value 0,027 dan memenuhi syarat uji chisquere yaitu dengan 0 cell $(0.0 \%)$ dan nilai harapan (expected count) adalah 10.58 sehingga terdapat hubungan yang bermakna antara status gizi dengan kejadian sindrom pre menstruasi pada siswi SMA Wirausaha Bandungan. Disarankan bagi remaja sebaiknya menjaga berat badan dengan mengkonsumsi makanan yang bergizi seimbang agar dapat menjadikan berat badan normal dan juga terhindar penyakit akibat kelebihan berat badan.
\end{abstract}

Corresponding author:

Priyanto

priyanto_araaf@yahoo.co.id

Jurnal Ilmu Keperawatan Maternitas, Vol 1 No 2, Nov 2018

e-ISSN 2621-2994

pinggul melebar dan membesar sehingga tidak terlihat seperti anak kecil lagi (Proverawati, 2009).

Setiap bulan wanita melepaskan satu sel telur dari salah satu ovariumnya. Bila sel telur ini tidak mengalami pembuahan maka akan terjadi perdarahan (menstruasi). Seorang wanita pada masa remaja lebih 
rentan mengalami permasalahanpermasalahan yang terkait pada saat menstruasi. Terjadinya menstruasi merupakan perpaduan antara alat genetalia dan rangsangan hormonal yang kompleks yang berasal dari rantai hipotalamushipofisisovarium (Proverawati, 2009).

Biasanya 7-10 hari sebelum terjadi menstruasi, wanita akan mengalami beberapa gejala perubahan tertentu, dari segi fisik (nyeri payudara, sakit kepala, jerawat, nyeri panggul bahkan edema maupun emosional (perubahan mood, penurunan fungsi sosial, penurunan konsentrasi, bahkan depresi yang akan mereda ketika siklus menstruasi dimulai. Namun pada beberapa wanita juga dapat terjadi gejala yang terus berlanjut hingga 24-48 jam pertama siklus menstruasi dan akan mereda selama beberapa hari ke depan. Gejala-gejala tersebut biasa dikenal dengan sindrom pramenstruasi (PMS) (O'Brien dkk., 2007 dalam Ratikasari 2015).

Premenstrual Syndrome (PMS) merupakan suatu kumpulan keluhan dan atau gejala fisik, emosional, dan perilaku yang terjadi pada wanita usia reproduksi, yang muncul secara siklik dalam rentang waktu 7-10 hari sebelum menstruasi dan menghilang setelah darah haid keluar, yang terjadi pada suatu tingkatan yang mampu mempengaruhi gaya hidup dan pekerjaan wanita tersebut, dan kemudian diikuti oleh suatu periode waktu bebas gejala sama sekali (Suparman, 2011).

Bagi beberapa wanita gejala PMS dapat terjadi cukup parah, sehingga dapat menimbulkan dampak yang merugikan. Umumnya dampak dari PMS tersebut adalah gangguan aktivitas harian, seperti penurunan produktivitas kerja, sekolah, dan hubungan interpersonal penderita. Di samping itu PMS yang berat juga dapat berhubungan dengan kasus bunuh diri yang tinggi, tingkat kecelakaan, dan masalah kejiwaan akut (Tolossa dan Bekele, 2014 dalam Rtikasari 2015).

Salah satu faktor risiko sindroma premenstruasi adalah indeks massa tubuh (IMT). Status gizi adalah keadaan yang diakibatkan oleh adanya keseimbangan antara jumlah asupan (intake) zat gizi dan jumlah yang dibutuhkan (required) oleh tubuh untuk berbagai fungsi biologis, seperti pertumbuhan fisik, perkembangan, aktivitas atau produktivitas, pemeliharaan, kesehatan, dan lainnya (Depkes, 2006). Status gizi ini memiliki peranan yang cukup penting pada tingkat keparahan kejadian PMS. Hal ini dikarenakan seseorang yang mengalami kegemukan atau obesitas dapat meningkatkan risiko terjadinya peradangan (inflamasi) yang berujung pada meningkatnya risiko mengalami gejala PMS (Bussell, 2014).

Data dari World Health Organization (WHO) menyebutkan bahwa 38,45 \% wanita didunia mengalami permasalahan mengenai gangguan Pre Menstrual Syndrome. Menurut hasil penelitian yang dilakukan oleh American College of Obstetricians and Gynecologis dalam Saryono (2009) bahwa sedikitnya $85 \%$ dari wanita menstruasi mengalami minimal satu dari gejala PMS dan umumnya terjadi pada wanita usia 1450 tahun dengan gejala yang bervariasi dan berubah-ubah pada tiap wanita dari bulan ke bulan.

Berdasarkan hasil studi pendahuluan di D III Kebidanan Stikes Ngudi Waluyo Ungaran pada tanggal 19 juli 2016, peneliti berhasil mewawancarai 10 siswi dengan menyebarkan kuesioner gejala Sindrom Pre Menstruasi menggunakan 10 Pertanyaan, didapatkan bahwa 7 siswi (70\%) mengalami sindrom pre menstruasi dengan klasifikasi IMT kategori gemuk ada 4 siswi dan kategori normal ada 3 siswi. Selebihnya ada 3 siswi (30\%) tidak mengalami sindrom pre menstruasi dengan klasifikasi IMT 
kategori normal 2 siswi dan kurus 1 siswi. Kesimpulan dari fenomena ditempat penelitian bahwa sebagian besar yang mengalami sindrom pre menstruasi adalah mahasiswi dengan kategori gemuk.

Dari penelitian di Asia Pasifik, diketahui bahwa di Jepang, PMS dialami oleh 34\% populasi perempuan dewasa, di Hongkong, PMS dialami oleh $17 \%$ populasi perempuan dewasa, di Pakistan PMS dialami oleh 13\% populasi perempuan dewasa, di Australia PMS dialami oleh $43 \%$ populasi perempuan dewasa (Elvira, 2010).

Angka kejadian PMS di Indonesia dialami 70\%-90\% oleh wanita usia reproduktif dan 2\%-10\% mengalami gejala Premenstrual Syndrome berat.

Berdasarkan uraian tersebut peneliti tertarik untuk meneliti tentang "Hubungan Status Gizi dengan Kejadian Sindrom Pre Menstruasi pada siswi SMA Wirausaha Bandungan Tahun 2016".

\section{METODE}

Jenis penelitian yang digunakan adalah analitik kolerasi dengan menggunakan pendekatan cross sectional. Penelitian ini dilaksanakan di SMA Wirausaha Bandungan pada tanggal 26-27 Juli 2016. Populasi dalam penelitian ini adalah semua siswi SMA Wirausaha Bandungan yang berjumlah 79 siswi. Sampel dalam penelitian ini adalah semua siswi SMA Wirausaha Bandungan yang berjumlah 79 siswi. Sedangkan teknik pengambilan sampel dalam penelitian ini dilakukan dengan menggunakan Nonprobability sampling dengan teknik purposive sampling.

Pada penelitian ini analisis univariat menggunakan distribusi frekuensi yang dilakukan terhadap tiap variabel, yaitu variabel independen (Status Gizi) dan variabel dependen (Sindrom Pre Menstruasi).

Analisa bivariat dengan uji chi-square (x2) dengan taraf signifikan $(\alpha)=0,05$. Hasil penelitian didapatkan bahwa $p$ value 0,027 dan memenuhi syarat uji chi-square yaitu dengan 0 cell $(0.0 \%)$ dan nilai harapan (expected count) adalah 10.58 .

\section{HASIL}

\section{Analisis Univariat}

\section{Status Gizi pada Siswi SMA Wirausaha Bandungan}

Tabel 1

Distribusi Frekuensi Status Gizi pada siswi SMA Wirausaha Bandungan Tahun 2016

\begin{tabular}{clll}
\hline No & Status Gizi & N & $\%$ \\
\hline 1. & Kurus & 22 & 27,8 \\
\hline 2. & Normal & 24 & 30,4 \\
\hline 3. & Gemuk & 33 & 41,8 \\
\hline & jumlah & 79 & 100
\end{tabular}

Sumber : Data Primer (2016)

Berdasarkan tabel 1 dapat didapatkan bahwa reponden sebanyak 33 orang $(41,8 \%)$ mengalami status gizi dalam kategori gemuk sedangkan yang mengalami status gizi dalam kategori normal sebanyak 24 responden $(30,4 \%)$ dan responden yang mengalami status gizi dalam kategori kurus sebanyak 22 responden $(41,8 \%)$.

\section{Kejadian Sindrom Pre Menstruasi pada Siswi SMA Wirausaha Bandungan}

Tabel 2

Distribusi Frekuensi Kejadian Sindrom Pre Menstruasi pada siswi SMA Wirausaha Bandungan Tahun 2016

\begin{tabular}{llcc}
\hline No & $\begin{array}{l}\text { Kejadian } \\
\text { Sindrom }\end{array}$ & N & $\%$ \\
& Pre Menstruasi & & \\
\hline 1 & Mengalami & 41 & 51,9 \\
2 & Tidak & 38 & 48,1 \\
& Mengalami & & \\
\hline & Jumlah & & 100 \\
\hline
\end{tabular}

Sumber : Data Primer (2016) 
Berdasarkan tabel 2 dapat didapatkan bahwa reponden sebanyak 41 orang $(51,9 \%)$ mengalami sindrom pre menstruasi sedangkan responden yang tidak mengalami sindrom pre menstruasi sebanyak 38 responden $(48,1 \%)$.

\section{Analisis Bivariat}

\section{Hubungan Status Gizi dengan Kejadian Sindrom Pre Menstruasi}

Tabel 3

Hubungan Status Gizi dengan Kejadian

Sindrom Pre Menstruasi pada siswi SMA Wirausaha Bandungan Tahun 2016

\begin{tabular}{|c|c|c|c|c|c|}
\hline \multirow[b]{2}{*}{$\begin{array}{c}\text { Status } \\
\text { Gizi }\end{array}$} & \multicolumn{2}{|c|}{$\begin{array}{l}\text { Kejadian Sindrom } \\
\text { Pre Menstruasi }\end{array}$} & \multirow{2}{*}{\multicolumn{2}{|c|}{ Total }} & \multirow[b]{2}{*}{$\begin{array}{c}\rho \\
\text { value }\end{array}$} \\
\hline & $\begin{array}{l}\text { Mengala } \\
\text { mi }\end{array}$ & $\begin{array}{l}\text { Tidak } \\
\text { Mengala } \\
\text { mi }\end{array}$ & & & \\
\hline & $\%$ & $\mathrm{~F} \quad \%$ & $f$ & $\%$ & \\
\hline 1 Kurus & 40,9 & $13 \quad 59,1$ & 22 & 100 & 0,027 \\
\hline 2 Normal & 37,5 & $15 \quad 62,5$ & 24 & 100 & \\
\hline 3 Gemuk & 69,7 & $10 \quad 30,3$ & 33 & 100 & \\
\hline Total & 51,9 & $38 \quad 48,1$ & 79 & 100 & \\
\hline
\end{tabular}

Berdasarkan tabel 3 dapat diketahui bahwa dari 79 responden yang mengalami sindrom pre menstruasi dengan status gizi kurus sebanyak 9 responden $(40,9 \%)$ dan yang tidak mengalami sindrom pre menstruasi sebanyak 13 responden (59,1\%). Responden yang mengalami sindrom pre menstruasi dengan status gizi normal sebanyak 9 responden $(37,5 \%)$ dan yang tidak mengalami sindrom pre menstruasi sebanyak 15 responden (62,5\%). Sedangkan responden yang mengalami sindrom pre menstruasi dengan status gizi gemuk lebih besar dibandingkan responden yang mengalami sindrom pre menstruasi dengan status gizi kurus dan normal yaitu sebanyak 23 responden $(69,7 \%)$ dan yang tidak mengalami sindrom pre menstruasi sebanyak 10 responden $(30,3 \%)$.

Berdasarkan hasil uji statistik Chi-Square didapat nilai $p$ value $<$ ? $(0,027<0,05)$, hal ini menunjukkan bahwa ada hubungan bermakna antara status gizi dengan kejadian sindrom pre menstruasi pada siswi SMA Wirausaha Bandungan Tahun 2016.

\section{PEMBAHASAN}

\section{Analisis Univariat}

\section{Status Gizi pada Siswi SMA Wirausaha Bandungan}

Pada penelitian ini dari 79 responden di SMA Wirausaha Bandungan didapatkan sebagian besar responden dengan status gizi gemuk lebih besar dibandingkan dengan status gizi kurus dan normal yaitu sebanyak 33 responden $(41,8 \%)$.

Status gizi lebih merupakan keadaan gizi seseorang dimana jumlah energi yang masuk ke dalam tubuh lebih besar dari jumlah energi yang dikeluarkan. Hal ini terjadi karena jumlah energi yang masuk melebihi kecukupan energi yang dianjurkan untuk seseorang, akhirnya kelebihan zat gizi disimpan dalam bentuk lemak yang dapat mengakibatkan seseorang menjadi obesitas (Hasdianah, 2012).

Hasil penelitian ini sejalan dengan penelitian Namsa (2015) di SMA Frater Don Bosco Manado bahwa responden dengan status gizi gemuk berjumlah 29 responden (48,3\%), lebih besar dibandingkan dengan responden dengan status gizi kurus berjumlah 8 responden $(13,3 \%)$ dan responden dengan status gizi normal berjumlah 23 responden $(38,3 \%)$.

\section{Kejadian Sindrom Pre Menstruasi pada Siswi SMA Wirausaha Bandungan}

Pada penelitian ini dari 79 responden di SMA Wirausaha Bandungan didapatkan responden yang mengalami sindrom pre menstruasi sebanyak 41 responden $(51,9 \%)$ lebih besar dibandingkan dengan 
responden yang tidak mengalami sindrom pre menstruasi yaitu sebanyak 38 responden $(48,1 \%)$.

Hasil penelitian ini sejalan dengan penelitian Ratnaningtyas (2012) pada siswi SMAN 2 Ngawi bahwa responden yang mengalami sindrom pre menstruasi sebanyak 62 responden (72,94\%) lebih besar dibandingkan dengan yang tidak mengalami sindrom pre menstruasi yaitu sebanyak 23 responden $(27,06 \%)$.

Dampak dari PMS bagi remaja putri yang bersekolah dapat menganggu kualitas kesehatan, konsentrasi, prestasi dan keaktifan kegiatan belajar di sekolah. Apalagi berdasarkan hasil penelitian ini diketahui bahwa sebagian besar $(51,9 \%)$ siswi SMA Wirausaha Bandungan mengalami sindrom pre menstruasi yang kemungkinan besar dapat menganggu aktivitas sosial di sekolah.

Pada penelitian ini menggunakan kuesioner dari SPAF (The Premenstrual Shortened Form) untuk mengukur kejadian sindrom pre menstruasi yaitu kriteria diagnose dengan penilaian sederhana yang terdiri dari 10 item. Masing-masing item mempunyai nilai maksimal 6 , terentang pada gejala yang tidak dirasakan sampai gejala yang sangat berat.

Pada penelitian ini didapatkan sebagian beasar responden banyak menjawab pernyataan pada nilai 5 yaitu pada pernyataan "merasa ingin marah atau emosi (mudah tersinggung), hal tersebut dapat disebabkan oleh ketidak seimbangan hormone estrogen dan progesterone. Hormone estrogen terlalu tinggi dibandingkan dengan hormone progesterone. Selain itu dapat pula disebabkan oleh faktor stress, kekurangan asam amino tyrosine, penyerapan dan penyimpanan timbul ditubuh, atau kekurangan magnesium dan vitamin B (terutama B6) (Andira, 2010).

Pada penelitian ini didapatkan responden paling sedikit menjawab pernyataan dengan nilai 1 yaitu pada pernyataan "merasa membengkak pada seluruh tubuh" hal tersebut dapat disebabkan oleh pembengkakan yang terjadi akibat berkumpulnya air pada jaringan diluar sel (ekstrasel) karena tingginya asupan garam atau gula pada diet penderita dan sebagian besar responden mengalami gejala sindrom pre menstruasi pada faktor psikologi seperti merasa ingin marah atau emosi (mudah tersinggung) dan pada faktor fisik sebagian besar responden mengalami nyeri dan pembesaran pada payudara dan merasa tidak nyaman atau nyeri pada bagian perut.

\section{Analisis Bivariat}

\section{Hubungan Status Gizi dengan Kejadian Sindrom Pre Menstruasi}

Pada penelitian ini diketahui bahwa Hasil uji Chi-Square menunjukkan ada hubungan bermakna antara status gizi dengan kejadian sindrom pre menstruasi dengan nilai $p$ value $0,027<\alpha=0,05$. Hal ini sejalan dengan teori Arisman, (2008) bahwa Hiperestrogenisme atau sebuah kondisi produksi estrogen diatas normal pada perempuan yang mengalami overweight, disebabkan peningkatan persentase lemak di dalam tubuh. Diketahui bahwa lemak terutama kolesterol merupakan bahan dasar pembentukan estrogen. Penelitian ini didukung oleh hasil penelitian Namsa (2015) yang menyatakan bahwa ada hubungan antara status gizi dengan sindrom pre menstruasi pada remaja putri di SMA Frater Don Bosco Manado didapatkan $\rho$ value 0,000 .

Masalah ini yang diakibatkan karena rendahnya kadar serotonin dalam tubuh. Padahal kadar serotonin di otak akan 
menurun jika IMT semakin tinggi. Serotonin ini berhubungan dengan reaksi neurotransmitter yang mengendalikan akses rangsangan kepada HipothalamusPituitary-Adrenal (HPA). Jika terjadi disfungsi pada aksis HPA ini, maka melalui manifestasi tertentu akan muncul gejala SPM. Hal ini di anggap sebagai sesuatu yang terhubung dengan aktivitas serotonin di dalam otak. Penderita SPM juga mempunyai keinginan yang meningkat terhadap konsumsi karbohidrat akibat rendahnya hormon serotonin (Saryono dan Waluyo, 2009).

Estrogen akan mengikat secara cepat pada saat terjadi pematangan folikel yang akan merangsang Luteinizing hormon. Hormon ini akan merangsang ovulasi yang muncul 14 hari sebelum menstruasi dan berakhir pada saat berhentinya fase folikuler. Pada fase Luteal LH menyebabkan sel granulosa dari folikel yang rupture dan akan membentuk corpus luteum, yang akan menghasilkan progesteron dalam jumlah besar dan sedikit estrogen. Fase luteal ditandai dengan berkurangnya produksi ovarium terhadap estrogen dan peningkatan produksi progesteron oleh corpus luteum yang mencapai puncaknya pada pertengahan fase luteal , kadar LH dan FSH kembali rendah. Bila tidak terjadi fertilisasi ovum akan mengalami degenerasi menjadi corpus luteum yang akan menyebabkan turunnya kadar progesteron dan estrogen secara cepat. Penurunan kadar progesteron dan esterogen ini menghasilkan kerusakan dan peluruhan dinding endomentrium, yang selanjutnya ditandai sebagi hari pertama dari siklus menstruasi berikutnya (Johnson, 2006).

Namun pada penelitian ini didapatkan juga bahwa sebanyak 10 responden $(30,3 \%)$ dengan status gizi gemuk yang tidak mengalami sindrom pre menstruasi. Hal ini dapat disebabkan adanya faktor lain yang lebih dominan seperti faktor genetik dan faktor psikologis. Dimana faktor genetik memainkan peranan yaitu insidensi pre menstruasi dua kali lebih tinggi pada kembar satu telur (monozigot) dibanding kembar dua telur, sedangkan faktor psikologis (psikis) yaitu stres sangat besar pengaruhnya terhadap kejadian pre menstruasi. Gejala-gejala pre menstruasi akan semakin menghebat jika didalam diri seorang wanita terus menerus mengalami tekanan (Saryono, 2009).

\section{KESIMPULAN}

1. Status gizi paling banyak dalam kategori status gizi gemuk yaitu sebanyak 33 responden $(41,8 \%)$.

2. Kejadian Sindrom Pre Menstruasi yang mengalami sebanyak 41 reponden $(51,9 \%)$

3. Ada Hubungan yang bermakna Status Gizi dengan Kejadian Sindrom Pre Menstruasi dengan $p$ value 0,027 .

\section{REFERENSI}

Andira, D. 2010. Seluk-Beluk Kesehatan Reproduksi Wanita. Jogjakarta : A+Plus Books

Arisman. 2010. Gizi dalam Daur Kehidupan. Jakarta : EGC

Dahlan, S. 2014. Statistik. Jakarta : Epidemiologi Indonesia

Dewi. 2012. Bahan Pangan, Gizi, dan Kesehaan. Bandung : Alfabeta

Dewi, R. 2012. Tiga fase Penting Pada Wanita. Jakarta : PT Gramedia

Elvira, S. D. 2010. Sindrom Pra-Menstruasi, Normalkah? Jakarta : FKUI

Hasdinah, dkk. 2014. Gizi. Yogyakarta : Nuha Medika

Priyanto - Hubungan Status Gizi dengan Kejadian Sindrom Pre Menstruasi Pada Siswi SMA Wirausaha Bandungan Tahun 2016 
Notoatmodjo, S. 2010. Metodologi Penelitian Kesehatan.

Proverawati, A. 2010. Obesitas dan Gangguan Makan Pada Remaja. Yogyakarta : Nuha Medika

Ratika, I. 2015. Faktor yang berhubungan dengan kejadian sindrom premenstruasi (PMS). Diakses tanggal 19 maret 2016 http://repository.uinjkt.ac.id/dspace/ bitstream/123456789/28896/1/IND AH\%20RATIKASARI-FKIK.pdf 